\title{
CLINICAL PROFILE OF DOWN SYNDROME IN CHILDREN LESS THAN 14 YEARS IN A TERTIARY CARE HOSPITAL
}

\author{
Leena Das ${ }^{1}$, Mangal Charan Murmu², Satyapriya Sahoo ${ }^{3}$
}

${ }_{1}^{1}$ Associate Professor, Department of Paediatrics, SCB Medical College, Cuttack, Odisha, India.

${ }^{2}$ Associate Professor, Department of Paediatrics, SCB Medical College, Cuttack, Odisha, India.

${ }^{3}$ Resident Physician, SCB Medical College, Cuttack, Odisha, India.

\section{ABSTRACT}

\section{BACKGROUND}

Down syndrome is the most common and most easily recognised condition causing intellectual disability. Down syndrome occurs in 1 in 700 to 1 in 1000 live births.

The aim of this study was to evaluate the incidence and clinical profile of Down syndrome in children below 14 years.

\section{MATERIALS AND METHODS}

Children below 14 years who presented with symptoms of Down syndrome from $1^{\text {st }}$ December 2015 to $30^{\text {th }}$ November 2017 were included in this hospital-based case series study.

\section{RESULTS}

The hospital-based incidence was found to be $0.1 \%$. The mean age of presentation was found to be 28.6 months. The ratio of male: female was 1.57 . The mean maternal age at delivery was found to be 27.6 years. About $9.5 \%$ of Down syndromes were diagnosed antenatally. The first order children were more common (42.9\%) followed by second order (32.5\%). Diagnosis by using Hall's criteria was done in $94.4 \%$ cases. On karyotyping $94.4 \%$ had non-disjunction and $4.6 \%$ patient had translocation.

\section{CONCLUSION}

The chromosomal non-disjunction was the most common type of chromosomal abnormality in Down syndrome. Down syndrome is associated with significant systemic abnormalities and is not infrequent among mothers younger than 25 years of age. Early diagnosis and proper screening should be undertaken among these patients.

\section{KEY WORDS}

Down Syndrome, Intellectual Disability, Karyotyping.

HOW TO CITE THIS ARTICLE: Das L, Murmu MC, Sahoo S. Clinical profile of Down syndrome in children less than 14 years in a tertiary care hospital. J. Evolution Med. Dent. Sci. 2018;7(24):2874-2879, DOI: 10.14260/jemds/2018/648

\section{BACKGROUND}

Down syndrome is the most common and most easily recognised condition causing intellectual disability.[1] Down syndrome occurs in 1 in 700 to 1 in 1000 live births. [2] The most common type of Down syndrome accounting for $95 \%$ of cases is standard Trisomy 21 and is caused by an extra chromosome 21 . The other types are translocations where only some cells will contain the extra chromosome (Mosaic Trisomy 21).[1,3] The two sets of characteristics, most frequently associated with Down syndrome are a distinctive facial appearance and intellectual impairment. Indeed, it was the distinctive appearance and in particular the epicanthic fold that contributed to the identification of Down syndrome by Langdon Down (1866) and his association of people with Down syndrome with the 'Mongoloid race.'[4] Down syndrome is diagnosed at birth and the facial characteristics means the syndrome is easily identifiable to anyone the child comes into contact with from an early age. The people with Down syndrome will have some degree of intellectual

'Financial or Other Competing Interest': None.

Submission 22-04-2018, Peer Review 26-05-2018,

Acceptance 02-06-2018, Published 11-06-2018.

Corresponding Author:

Dr. Mangal Charan Murmu,

Qr. No. A/4, Doctors Colony,

Shishubhawan, Chandinichowk

Cuttack-753002, Odisha, India.

E-mail: mangal74murmu@yahoo.co.in

DOI: $10.14260 /$ jemds $/ 2018 / 648$

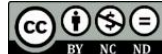

impairment, though the level of impairment varies from person to person. According to Carr (1988) children and adults with Down syndrome differ from one another in term of Intelligence Quotient (IQ) to a similar magnitude to people in the non-disabled population; that is people's IQs can differ by 50 to 60 IQ points. Recent behavioural phenotype research has identified a distinct profile of behavioural strengths and weaknesses associated with Down syndrome.[3] Behavioural phenotype research allows for a more fine grained understanding of abilities and the potential of children with genetic disorders than that provided by an IQ score.[3,5] The greater understanding can be achieved by investigating how the phenotypes develop and change overtime.[6] The Down syndrome behavioural phenotype includes relative strengths in areas of visual spatial processing compared with verbal processing. ${ }^{[7,8]}$ In particular, visual memory and visual motor integration appear to be areas of relative strength. ${ }^{[3,9]}$ Long term memory for words and pictures has also been found to be significantly difficult for children with Down syndrome. Social functioning has been generally considered to be an area of strength in children with Down syndrome.[10] Children with Down syndromes are stigmatised both for having an intellectual disability and for how they look.[5] So this study is planned to study the clinical profile of Down's syndrome.

\section{Aims and Objectives}

To evaluate the incidence and clinical profile of Down syndrome in children below 14 years. 


\section{MATERIALS AND METHODS}

After obtaining the ethical committee clearance from the Institutional Ethical Committee, the study was conducted. The children below 14 years who presented with symptoms of Down syndrome from 1st December 2015 to 30 th November 2017.

It is a hospital-based case series study. Selection of cases: All the children below 14 years with clinical and laboratory evidence of Down syndrome reported/admitted to outdoor/indoor of SVP PGIP and SCB Medical College during study period fulfilling the inclusion criteria were taken as cases after taking consent from parents. 126 patients were selected for the study.

Inclusion Criteria: All the children below 14 years of age presenting with the signs and symptoms of Down syndrome or diagnosed by Karyotyping and neonate fitting to Hall's criteria were included in the study.

Exclusion Criteria: The children with other syndromic associations, suspected with single gene disorders, inborn error of metabolism and multifactorial genetic diseases or other anomalies which are not diagnosed as Down syndrome were excluded from the study.

Hall's Criteria: Hypotonia, poor Moro's reflex, flat face, upward slanted palpebral fissure, small dysplastic ears, joint hyperflexibility, short neck, short fifth-digit clinodactyly, single transverse palmar crease and pelvic dysplasia.

\section{Investigation}

The following investigations were carried out in each case to determine the associated conditions. A. Blood: Complete blood count, comment on peripheral smear, thyroid function test, B. Bone marrow study, C. Radiological study: X-ray, Ultrasound of brain, abdomen, CT scan/ MRI, Barium meal follow-through, D. ECG, E. Echocardiography, F. EEG, G. Karyotyping, H. Ophthalmological examination: Slit lamp biomicroscopy, visual acuity testing, ophthalmoscopy; I. Audiological investigation: OAE, BERA.

\section{Statistical Analysis}

For statistical analyses, the data were done by chi-square test. The calculated $\mathrm{p}$-value is below the threshold chosen for statistical significance.

P-value $\leq 0.05$ was considered for statistical significance.

\section{RESULTS}

\begin{tabular}{|c|c|c|c|c|c|}
\hline \multicolumn{2}{|c|}{$\begin{array}{c}\text { Incidence: } \\
\text { 126/112949 }\end{array}$} & Male & Female & Frequency & $\%$ \\
\hline \multicolumn{2}{|c|}{ Total Patients } & 77 & 49 & 126 & 100 \\
\hline \multirow{3}{*}{$\begin{array}{c}\text { Age } \\
\text { Group }\end{array}$} & $\begin{array}{c}1 \text { year } \\
\text { years }\end{array}$ & 46 & 26 & 72 & 57.1 \\
\cline { 2 - 6 } & $>5$ years & 11 & 11 & 22 & 17.5 \\
\cline { 2 - 6 } & \multicolumn{6}{|c|}{ Table 1. Distribution of Incidence } \\
\hline \multicolumn{6}{|c|}{} \\
\cline { 2 - 6 }
\end{tabular}

The hospital-based incidence was found to be $0.1 \%$. Male: Female ratio being 1.57 .

\begin{tabular}{|c|c|c|}
\hline Maternal Age at Delivery in Years & Frequency & $\mathbf{\%}$ \\
\hline$<20$ & 13 & 10.3 \\
\hline $20-25$ & 37 & 29.4 \\
\hline $26-30$ & 27 & 21.4 \\
\hline
\end{tabular}

\begin{tabular}{|c|c|c|}
\hline $31-34$ & 31 & 24.6 \\
\hline$>35$ & 18 & 14.3 \\
\hline Total & $\mathbf{1 2 6}$ & $\mathbf{1 0 0}$ \\
\hline
\end{tabular}

Table 2. Distribution of Maternal Age at Delivery

The mean maternal age at delivery was found to be 27.6 years.

\begin{tabular}{|c|c|c|}
\hline Antenatal Diagnosis & Frequency & Percentage \\
\hline No & 114 & 90.5 \\
\hline Yes & 12 & 9.5 \\
\hline Total & $\mathbf{1 2 6}$ & $\mathbf{1 0 0}$ \\
\hline \multicolumn{2}{|c|}{ Table 3. Distribution of Antenatal Diagnosis } \\
\hline
\end{tabular}

About $9.5 \%$ of Down syndrome were diagnosed antenatally.

\begin{tabular}{|c|c|c|}
\hline Order & Frequency & Percentage \\
\hline $1^{\text {st }}$ & 54 & 42.9 \\
\hline $2^{\text {nd }}$ & 41 & 32.5 \\
\hline $3^{\text {rd }}$ & 24 & 19 \\
\hline $4^{\text {th }}$ & 6 & 4.8 \\
\hline $5^{\text {th }}$ & 1 & 0.8 \\
\hline Total & $\mathbf{1 2 6}$ & $\mathbf{1 0 0}$ \\
\hline \multicolumn{2}{|c|}{ Table 4. Distribution of Order of Births } \\
\hline
\end{tabular}

The first order children were found to be more common (42.9\%) followed by second order (32.5\%).

\begin{tabular}{|c|c|c|}
\hline Diagnosis using Hall's Criteria & Frequency & $\mathbf{\%}$ \\
\hline No & 7 & 5.6 \\
\hline Yes & 119 & 94.4 \\
\hline Total & $\mathbf{1 2 6}$ & $\mathbf{1 0 0}$ \\
\hline Table 5. Distribution of diagnosis using Hall's Criteria \\
\hline
\end{tabular}

The diagnosis by using Hall's criteria was $94.4 \%$.

\begin{tabular}{|c|c|c|}
\hline Karyotyping & Frequency & Percentage \\
\hline Non-disjunction & 94 & 74.6 \\
\hline Translocation & 5 & 4 \\
\hline Not done & 27 & 21.4 \\
\hline Total & $\mathbf{1 2 6}$ & $\mathbf{1 0 0}$ \\
\hline \multicolumn{2}{|c|}{ Table 6. Distribution of Karyotyping } \\
\hline
\end{tabular}

On karyotyping, 94.4\% had non-disjunction and $4.6 \%$ patient had translocation.

\begin{tabular}{|c|c|c|c|}
\hline \multirow{2}{*}{ Features } & \multicolumn{2}{|c|}{ Frequency } \\
\cline { 2 - 4 } & Epicanthic fold & 115 & 91.3 \\
\hline \multirow{4}{*}{$\begin{array}{c}\text { Craniofacial } \\
\text { dysmorphism }\end{array}$} & Flat facial facies & 99 & 78.6 \\
\cline { 2 - 4 } & Mongoloid slant & 117 & 92.9 \\
\cline { 2 - 4 } & Small dysplastic ear & 58 & 46 \\
\cline { 2 - 4 } & Brachycephaly & 28 & 22.2 \\
\cline { 2 - 4 } & Cleft lip & 9 & 7.1 \\
\cline { 2 - 4 } & Cleft palate & 2 & 1.6 \\
\cline { 2 - 4 } & Protruding tongue & 37 & 29.4 \\
\cline { 2 - 4 } & Low set ear & 56 & 44.4 \\
\hline \multirow{5}{*}{ CNS Feature } & Hypotonia & 81 & 64.3 \\
\cline { 2 - 4 } & Poor Moro reflex & 39 & 31 \\
\cline { 2 - 4 } & Motor develop delay & 65 & 51.6 \\
\cline { 2 - 4 } & Speech impairment & 38 & 30.2 \\
\cline { 2 - 4 } & Cognitive impairment & 26 & 20.6 \\
\cline { 2 - 4 } & Hearing impairment & 77 & 61.1 \\
\hline
\end{tabular}




\begin{tabular}{|c|c|c|c|}
\hline & Seizures & 4 & 3.2 \\
\hline & Autistic disorder & 1 & 0.8 \\
\hline & Behavioural disorder & 0 & 0 \\
\hline \multirow{6}{*}{ CVS Finding } & ASD & 5 & 4 \\
\hline & ECD & 10 & 7.9 \\
\hline & \begin{tabular}{|l|} 
Eisenmenger complex \\
\end{tabular} & 2 & 1.6 \\
\hline & Normal & 95 & 75.4 \\
\hline & TOF & 4 & 3.2 \\
\hline & VSD & 10 & 7.9 \\
\hline \multirow{6}{*}{$\begin{array}{l}\text { Ophthalmological } \\
\text { feature }\end{array}$} & Brushfield spot & 3 & 2.4 \\
\hline & Cataract & 4 & 3.2 \\
\hline & Hypertelorism & 40 & 31.7 \\
\hline & Normal & 72 & 57.1 \\
\hline & Nystagmus & 4 & 3.2 \\
\hline & Strabismus & 3 & 2.4 \\
\hline \multirow{9}{*}{ Limb Anomaly } & Sandal gap & 53 & 42.1 \\
\hline & Kennedy crease & 67 & 53.2 \\
\hline & Brachydactyly & 47 & 37.3 \\
\hline & Clinodactyly & 46 & 36.5 \\
\hline & Polydactyly & 5 & 4 \\
\hline & Simian crease & 42 & 33.3 \\
\hline & Sydney line & 31 & 24.6 \\
\hline & Increased ATD angle & 51 & 40.5 \\
\hline & $\begin{array}{c}\text { Mostly ulnar loops in } \\
\text { finger prints }\end{array}$ & 126 & 100 \\
\hline \multirow{4}{*}{$\begin{array}{l}\text { Haematological } \\
\text { disorder }\end{array}$} & ALL & 5 & 4 \\
\hline & AML & 2 & 1.6 \\
\hline & Normal & 108 & 85.7 \\
\hline & $\begin{array}{c}\text { Transient } \\
\text { myeloproliferative } \\
\text { disorder }\end{array}$ & 11 & 8.7 \\
\hline \multirow{2}{*}{ Thyroid disorder } & Normal & 115 & 91.3 \\
\hline & Hypothyroid & 11 & 8.7 \\
\hline \multirow{7}{*}{ G I Malformation } & Annular pancreas & 4 & 3.2 \\
\hline & Celiac disease & 2 & 1.6 \\
\hline & Duodenal atresia & 8 & 6.3 \\
\hline & Hirschsprung disease & 4 & 3.2 \\
\hline & Imperforate anus & 3 & 2.4 \\
\hline & \begin{tabular}{|c|} 
Tracheo-oesophageal \\
fistula
\end{tabular} & 5 & 4 \\
\hline & Normal & 100 & 79.4 \\
\hline \multirow{4}{*}{$\begin{array}{l}\text { Musculoskeletal } \\
\text { defect }\end{array}$} & Atlantoaxial instability & 23 & 18.3 \\
\hline & Hip dysplasia & 9 & 7.1 \\
\hline & Scoliosis & 4 & 3.2 \\
\hline & Normal & 90 & 71.4 \\
\hline \multirow{4}{*}{ Other features } & Recurrent RTI & 47 & 37.3 \\
\hline & Seborrhoeic dermatitis & 30 & 23.8 \\
\hline & $\begin{array}{c}\text { Obstructive sleep } \\
\text { apnoea }\end{array}$ & 15 & 11.9 \\
\hline & Delayed tooth eruption & 25 & 19.8 \\
\hline
\end{tabular}

The table shows the frequency of different presentation of clinical signs and symptoms of Down syndrome.

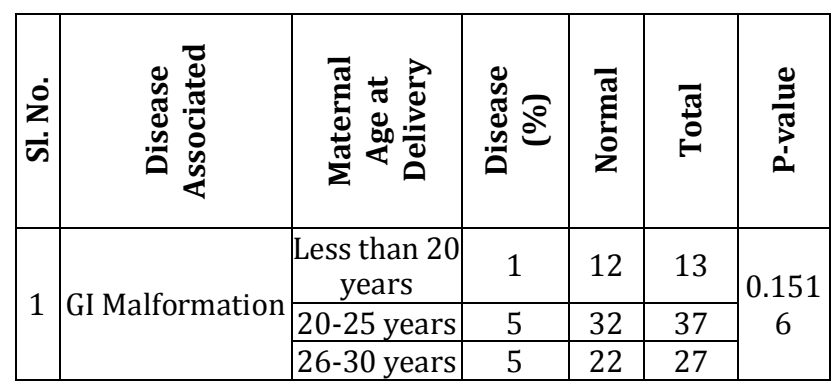

\begin{tabular}{|c|c|c|c|c|c|c|}
\hline & & 31-34 years & 8 & 23 & 31 & \\
\hline & & $\geq 35$ years & 7 & 11 & 18 & \\
\hline & \multirow{5}{*}{$\begin{array}{l}\text { Haematological } \\
\text { Disorder }\end{array}$} & \begin{tabular}{|c|} 
Less than 20 \\
years
\end{tabular} & 4 & 9 & 13 & \multirow{5}{*}{$\begin{array}{c}0.123 \\
9\end{array}$} \\
\hline 2 & & $20-25$ years & 6 & 31 & 37 & \\
\hline$z$ & & $26-30$ years & 1 & 26 & 27 & \\
\hline & & 31-34 years & 6 & 25 & 31 & \\
\hline & & $\geq 35$ years & 1 & 17 & 18 & \\
\hline \multirow{5}{*}{3} & \multirow{5}{*}{ CVS Disorder } & $\begin{array}{c}\text { Less than } 20 \\
\text { years }\end{array}$ & 3 & 10 & 13 & \multirow{5}{*}{$\begin{array}{c}0.467 \\
9\end{array}$} \\
\hline & & $20-25$ years & 13 & 24 & 37 & \\
\hline & & 26-30 years & 6 & 21 & 27 & \\
\hline & & 31-34 years & 5 & 26 & 31 & \\
\hline & & $\geq 35$ years & 4 & 14 & 18 & \\
\hline \multirow{5}{*}{4} & \multirow{5}{*}{ Hypothyroidism } & $\begin{array}{c}\text { Less than } 20 \\
\text { years }\end{array}$ & 2 & 11 & 13 & \multirow{5}{*}{$\begin{array}{c}0.640 \\
7\end{array}$} \\
\hline & & 20-25 years & 4 & 33 & 37 & \\
\hline & & $26-30$ years & 3 & 24 & 27 & \\
\hline & & 31-34 years & 1 & 30 & 31 & \\
\hline & & $\geq 35$ years & 1 & 17 & 18 & \\
\hline
\end{tabular}

Table 8. Disease/Deformity associated with Maternal Age

There is no statistical significance seen as far as maternal age and disease is concerned.

\begin{tabular}{|c|c|c|c|c|c|c|}
\hline $\begin{array}{l}\text { Sl. } \\
\text { No. }\end{array}$ & Disease & $\begin{array}{c}\text { Order } \\
\text { of } \\
\text { Birth }\end{array}$ & Present & Normal & Total & $\begin{array}{c}\text { P- } \\
\text { value }\end{array}$ \\
\hline \multirow{5}{*}{1} & \multirow{5}{*}{$\begin{array}{c}\text { GI } \\
\text { Malformation }\end{array}$} & $1^{\text {st }}$ & 10 & 44 & 54 & \multirow{5}{*}{0.4279} \\
\hline & & $2^{\text {nd }}$ & 9 & 32 & 41 & \\
\hline & & 3 rd & 4 & 20 & 24 & \\
\hline & & $4^{\text {th }}$ & 3 & 3 & 6 & \\
\hline & & $5^{\text {th }}$ & 0 & 1 & 1 & \\
\hline \multirow{5}{*}{2} & \multirow{5}{*}{$\begin{array}{c}\text { Haematological } \\
\text { Disorder }\end{array}$} & 1 st & 9 & 45 & 54 & \multirow{5}{*}{0.6678} \\
\hline & & $2^{\text {nd }}$ & 7 & 34 & 41 & \\
\hline & & $3^{\text {rd }}$ & 2 & 22 & 24 & \\
\hline & & $4^{\text {th }}$ & 0 & 6 & 6 & \\
\hline & & $5^{\text {th }}$ & 0 & 1 & 1 & \\
\hline \multirow{5}{*}{3} & \multirow{5}{*}{ CVS Disorder } & $1^{\text {st }}$ & 10 & 44 & 54 & \multirow{5}{*}{0.2775} \\
\hline & & 2nd & 12 & 29 & 41 & \\
\hline & & $3^{\text {rd }}$ & 7 & 17 & 24 & \\
\hline & & $4^{\text {th }}$ & 1 & 5 & 6 & \\
\hline & & $5^{\text {th }}$ & 1 & 0 & 1 & \\
\hline \multirow{5}{*}{4} & \multirow{5}{*}{ Hypothyroidism } & $1^{\text {st }}$ & 4 & 50 & 54 & \multirow{5}{*}{0.8749} \\
\hline & & $2^{\text {nd }}$ & 3 & 38 & 41 & \\
\hline & & 3 rd & 3 & 21 & 24 & \\
\hline & & $4^{\text {th }}$ & 1 & 5 & 6 & \\
\hline & & $5^{\text {th }}$ & 0 & 1 & 1 & \\
\hline
\end{tabular}

Table 9. Diseases/Deformity associated with birth order

There is no statistical significance seen as far as birth order and disease is concerned.

\section{DISCUSSION}

Out of total number of 112949 reported cases in OPD and IPD, Department of Paediatrics in the expected age group during the study period, 126 cases fulfilling the inclusion criteria were included in the present study.

The incidence of Down syndrome in our study was found to be $0.1 \%$. Jaruratanasirikul $\mathrm{S}$ et al found a prevalence of Down syndrome to be 1.21 per 1000 births in a populationbased study in Southern Thailand. Ram Lakhan[10] et al found the prevalence of Down syndrome to be 1.45 in tribal population, which is greater than our study. It might be due to environmental and genetic factors. Hospital based 
incidence could not be compared with large population-based study, as the incidence or prevalence were calculated in a large scale population and in community based manner.

The ratio of male-to-female being 1.57 in our study. Kava MP and Tullu MS, Muranjan MM and Girisha KM (2005)[11] found this ratio of 1.37 in their study, which was just lower to our study. This might be due to lesser sample size of our study. KR Lahiri and Satish observed that this ratio of 1.47 , which is almost similar to our study. The excess of male appears to be universal and was reported in all studies in different countries and ranged from 1.1: 1 to 2.3: 1 . Kovaleva $\mathrm{NV}^{[12]}$ study concluded that the sex ratio was skewed towards excess of males in majority.

In our study, 9.5\% of patients of Down syndrome were diagnosed in antenatal period. Gilany et al[13] in a study on Down syndrome in Mansoura, Egypt found all Down syndrome cases diagnosed after birth. About $42.9 \%$ were first child of their mother, which could be compared to the study of Gilany et al.[13] About $94.4 \%$ of children were diagnosed by Hall's criteria in our study.

Out of 99 patients in whom karyotyping was done, $94.4 \%$ showed non-disjunction and $4.6 \%$ had translocation. $21.4 \%$ patients did not get it done in our study. Kava et al[11] found free trisomy (non-disjunction in 95\%), translocation in 3.2\% and mosaicism in $1.8 \%$. Gilany et al found non-disjunction was most common (96.1\%) followed by translocation (3.1\%) than mosaic $(0.8 \%)$. DS Wang YF et al[14] found that $93.02 \%$ had non-disjunction and translocation in $3.4 \%$ patients. All the studies done were found to have almost similar proportion in karyotyping.

In our study physical finding that were most prominent were epicanthic folds, flat facial facies, mongoloid slant, small dysplastic ear, brachycephaly, cleft lip and cleft palate which corresponds to $78.6 \%, 91.3 \%, 92.9 \%, 46 \%, 22.2 \%, 7.1 \%$ and $1.6 \%$ respectively. Low set ear were found in $44.4 \%$ of cases. Kava et al noted mongoloid slant in $83.9 \%$, epicanthal fold in $56.9 \%$, ear abnormality in $66.9 \%$ and flat facial facies in $50.9 \%$ cases. Källén B et al[15] studied that there was elevated risk ratio of cleft lip and cleft palate around 3 - 5 in cases of Down syndrome in their 5581 collected samples. Irfan Ahmed et al[16] showed that brachycephaly was seen in $40 \%$ of cases in their study. This might be due to geographical variation.

Around $64.3 \%$ children had hypotonia, 31\% children showed poor Moro reflex, all of them were below 8 months age. $51.6 \%$ patients were found to have features of delayed motor development. $30.2 \%$ children showed features of delay in speech and articulation problems which could be compared with the study by Abbeduto L, Warren SF and Conners FA.[17] Stuttering was found to be present in 10-45\% of Down syndrome studied by Ray D Kent and Houri K Vorperian.[18] Pueschel SM[19] showed that epilepsy occurs in $1 \%$ to $13 \%$ of children with Down syndrome. Capone G, Goyal $\mathrm{P}$, Ares W and Lannigan $\mathrm{E}^{[20]}$ showed that neurobehavioural and psychiatric comorbidity in children with Down syndrome range from $18 \%$ to $38 \%$ which was higher than our study. Kava et al found that $76.3 \%$ cases had hypotonia in their study, which is similar to our study. Arya et al[21] and Lujic et al[ $^{[22]}$ estimated that $5-13 \%$ children with Down syndrome had seizures. It was slightly higher than our study. Irfan Ahmed et al[16] found that delayed developmental delay was seen in $68.5 \%$, which was lower than our study. Neerja
Agarwal Gupta et al[23] found that hearing loss could be conductive or sensorineural and seen in $75 \%$ of children with Down syndrome and majority of patients had serous otitis media, which was higher than our study. Raut et al ${ }^{[24]}$ in their study showed the incidence of hearing loss in first year of life which was $34.1 \%$. Nightingale $\mathrm{E}$ et al[25] in their study found that permanent hearing loss was found in $24.9 \%$ of cases. Most common cardiovascular abnormality in our study was VSD (7.9\%) and endocardial cushion defect (7.9\%) followed by ASD (4\%). TOF was seen in $3.2 \%$ cases and Eisenmenger complex in $1.6 \%$ cases. Kava et al found VSD in $25.8 \%$ cases, TOF in $15.5 \%$ cases and ASD in $12.1 \%$ cases. Benhaourech Sanna et al in their study from 2156 patients with CHD, 128 were identified with Down syndrome where most common was Endocardial cushion defects in $29 \%$ followed by VSD in $21.5 \%$ cases comparable to our study. In the study of Gilany et al they had seen CHD in 18.9\% cases of Down syndrome cases, which were $24.6 \%$ cases. In their study, most common defect was VSD in 7.9\% cases, which was similar to our study. Irfan Ahmed et al found CHD in 39.4\% cases which included VSD in $36.9 \%$ cases, which included VSD in $36.9 \%$ cases, ECD in $33 \%$ cases, ASD in $14.5 \%$ cases and TOF in $7.8 \%$ of children. Lahiri et al said that ECD to be the most common CHD followed by VSD in their study. The most common ophthalmological finding was Hypertelorism in $31.7 \%$ cases followed by Cataract and Nystagmus 3.2\% cases separately, Brushfield spot in $2.4 \%$ patients and Strabismus in $2.4 \%$ cases. Kava MP et al[11] found Hypertelorism (33.9\%), Nystagmus (3.2\%), Brushfield spot (3.2\%), Strabismus $(2.7 \%)$ and Cataract $(1.9 \%)$ which is comparable to our study. Irfan Ahmed et al[16] demonstrated Hypertelorism (62.4\%), Nystagmus (6.1\%), Brushfield spot (5.4\%), Strabismus (6.4\%) and Cataract (1.9\%), which was slightly higher than our study. Wong $\mathrm{V}$ et al[26] found strabismus in $20 \%$ and nystagmus in $11 \%$ of cases in their study. Dermatoglyphics features like sandal gap, Kennedy line, brachydactyly, clinodactyly, polydactyly, simian crease, Sydney line, increased ATD angle and Ulnar loop represents $42.1 \%, 53.2 \%, 37.3 \%, 36.5 \%, 4 \%, 33.3 \%, 24.6 \%, 40.5 \%$ and $100 \%$ cases respectively. Kava et al found sandal gap in $46.2 \%$, simian crease in $33.2 \%$, clinodactyly in $36.1 \%$ and brachydactyly in $11.1 \%$ respectively which could be comparable to our study. Irfan Ahmed et al said that in their study sandal gap was present in $46.4 \%$ cases, clinodactyly in $24.7 \%$, simian crease in $64.7 \%$ and brachydactyly in $23.7 \%$ cases. S. Rajangam et al[27] told that in their study, out of 235 Down syndrome cases the ATD angle deferred significantly from control, i.e. more than 80 and mostly ulnar loop pattern observed in all cases. Castilla EE et al[28] found association between polydactyly and Down syndrome in a retrospective study.

Brink DS[29] found that transient myeloproliferative disorder of Down syndrome occurred in approximately $10 \%$ of Down syndrome neonates and in phenotypically normal neonates with trisomy 21 mosaicism which is similar to our study. John $\mathrm{K}$ Choi[30] found that up to $10 \%$ of all Down syndrome patients have transient myeloproliferative disorder, although more recent studies found lower percentage (3 to 6\%). In all three studies including our study, transient myeloproliferative disorder was the most common haematological disorder. 
Irfan Ahmed et al[17] found hypothyroidism in $7.1 \%$ cases and Gilany et al found $7.9 \%$ of cases of Down syndrome which is comparable to our study. Kava et al found GI anomalies in 7 cases, Down syndrome which included 3 cases of imperforated anus, 2 cases of Hirschsprung disease, 1 case of duodenal atresia and 1 case of Morgagni hernia; whereas Irfan et al found $1.7 \%$ cases of imperforated anus, tracheooesophageal fistula in $1.3 \%$ cases, Hirschsprung disease in $1 \%$ and duodenal atresia in $0.7 \%$ cases which is lower than our study. Fawzi Elhami Ali et al[31] had observed that Atlantoaxial instability affected $10-20 \%$ of individuals, which is comparable to our study.

G Ram et al[32] found around $45 \%$ of $1-3$ years old children followed by less than 1 year of age were admitted for respiratory cause, which is similar to our study. Ondarza A et al[33] found delayed eruption of teeth in patients with Down syndrome. On contrary to this in our study, only $19.8 \%$ cases had delayed dentition.

Irfan Ahmed et al found that $56.7 \%$ with trisomy had maternal age of $>35$ years, which is different from our study. Jyothy et al[34] documented that the Down syndrome cases were born to younger mothers $(<25$ years).

The statistically insignificant values were observed in almost all cases. It might be due to less number of cases, shorter duration of study period or the changing pattern of presentation of Down syndrome. Further studies are required to obtain statistical significance.

\section{SUMMARY}

The hospital-based incidence was found to be $0.1 \%$. The mean age of presentation was found to be 28.6 months. The ratio of male: female was 1.57 . The mean maternal age at delivery was found to be 27.6 years. About $9.5 \%$ of Down syndrome were diagnosed antenatally. The first order children were found to be more common (42.9\%) followed by second order (32.5\%). The diagnosis by using Hall's criteria were $94.4 \%$. On karyotyping, 94.4\% had nondisjunction and $4.6 \%$ patients had translocation. The distribution of craniofacial dysmorphism showed flat facies in $78.6 \%$, epicanthal fold in $91.3 \%$ cases, Mangoloid slant in $92.9 \%$ cases, small dysplastic ear in $46 \%$, brachycephaly in $22.2 \%$ cases, cleft lip in $7.1 \%$, cleft palate in $1.6 \%$, patients with open mouth protruding tongue in $29.4 \%$ cases and lowest ear in $44.4 \%$ cases. In CNS features, Hypotonia was present in $64.3 \%$ of cases. Poor Moro's reflex in $31 \%$ cases, motor developmental delay in $51.6 \%$ cases, speech impairment in $30.2 \%$ cases, cognitive impairment in $20.6 \%$ cases, hearing impairment in $61.1 \%$ cases, seizures in $3.2 \%$ of cases and autism in $0.8 \%$ cases. In Echocardiography finding ECD and VSD both were present in 7.9\% of cases, ASD in $4 \%$ cases, TOF in $3.2 \%$ cases and Eisenmenger complex in $1.6 \%$ cases. In ophthalmological finding hypertelorism being most common was present in $31.7 \%$ cases, nystagmus and cataract was found in $3.2 \%$ cases each, Brushfield spot and strabismus in $2.4 \%$ cases. Limb and dermatoglyphics feature showed sandal gap in $42.1 \%$ cases, Kennedy crease in $53.2 \%$ cases brachydactyly in $37.3 \%$ cases, clinodactyly in $36.5 \%$ cases, polydactyly in $4 \%$ cases, simian crease in $33.3 \%$ cases, Sydney line in $24.6 \%$ cases and increased ATD angle in $40.5 \%$ cases. We found mostly ulnar loops in fingerprints in $100 \%$ cases. Transient myeloproliferative disorder (8.7\%) was found to be most common haematological disorder in our study followed by AML (4\%) and ALL (1.6\%). Hypothyroidism was found to be present in $8.7 \%$ of cases in our study. Duodenal atresia was found to be most common GI malformation, i.e. $6.3 \%$ cases followed by tracheooesophageal fistula in $4 \%$ cases, annular pancreas in $3.2 \%$ cases, imperforated anus in $2.4 \%$ cases and coeliac disease in $1.6 \%$ cases. Atlantoaxial instability was found to be the most common $(18.3 \%)$ followed by hip dysplasia $(7.1 \%)$ and scoliosis in $3.2 \%$ cases in musculoskeletal defects. Around 87.3\% cases were coming to hospital for recurrent respiratory tract infections. Around $23.8 \%$ cases were having seborrhoeic dermatitis and $19.8 \%$ of cases were having delayed tooth eruption. Most number of Down syndrome patients $(29.4 \%)$ have delivered from mother of age group of 20 - 25 years followed by 31 - 34 years (24.6\%) cases and 26 - 30 years of age in $21.4 \%$ of cases.

\section{CONCLUSION}

The chromosomal non-disjunction was the most common type of chromosomal abnormality in Down syndrome. The early presentation of Down syndrome in our setup is due to the hospital delivery and referral from the nearby community health centre. Down syndrome is associated with significant systemic abnormalities and is not infrequent among mothers younger than 25 years of age. Early diagnosis and proper screening should be undertaken among these patients. There must be a review for the recurrence risk in subsequent pregnancies and availability of prenatal diagnosis as provided in genetic counseling. The patients must be undergoing audiological evaluation annually, ophthalmologic evaluation every 2 yearly, TSH evaluation annually and other investigations must be at proper intervals. Effective early stimulation therapy, behavioural intervention, positive home environment, education, vocational training, occupational therapy, speech therapy and physiotherapy are helpful in improving the overall functioning and productivity of these children. Accurate and latest information must be provided in a supportive and empathetic manner.
Abbreviations
AAI: Atlantoaxial Instability.
ALL: Acute Lymphoblastic Leukaemia.
AML: Acute Myeloblastic Leukaemia.
ARDS: Acute Respiratory Distress Syndrome.
ASD: Atrial Septal Defect.
ASM: Autistic Spectrum Disorder.
ATD: Axial Triradius.
BERA: Brainstem Evoked Response Audiometry.
CBC: Complete Blood Count.
CHD: Congenital Heart Disease.
CPS: Comment on Peripheral Smear.
CT: Computed Tomography.
CVS: Chorionic Villus Sampling.
ECD: Endocardial Cushion Defect.
ECG: Electrocardiograph.
EEG: Electroencephalograph.
G I: Gastrointestinal.
IQ: Intelligence Quotient.
MDD: Motor Developmental Delay.
MRI: Magnetic Resonance Imaging.
OAE: Otoacoustic Emissions.
TFT: Thyroid Function Test.
TMD: Transient Myeloproliferative Disorder. 
TOF: Tetralogy of Fallot.

USG: Ultrasonography.

VSD: Ventricular Septal Defect.

\section{REFERENCES}

[1] Carr J. Down's syndrome: children growing up. 1st edn. Cambridge, UK: Cambridge University Press 1995.

[2] Stoll C, Alembik Y, Dott B, et al. Epidemiology of Down syndrome in 118,265 consecutive births. Am J Med Genet Suppl 1990;7:79-83.

[3] Fidler DJ. The emerging Down syndrome behavioral phenotype in early childhood: implications for practice. Infants and Young Children 2005;18(2):86103.

[4] Jahoda A, Cattermole M, Markova I. Quality of life: hope for the future or an echo from the distant past? In: Markova I, Farr R, eds. Representations of health, illness and handicap. Amsterdam: Harwood 1995: p. 205-24.

[5] Buckley SJ. Attaining basic educational skills: reading, writing and number. In: Lane D, Stratford B, eds. Current approaches to Down's syndrome. Eastbourne: Holt, Rinehart \& Winston 1985: p. 315-43.

[6] Karmiloff-Smith A. Development itself is the key to understanding developmental disorders. Trends Cogn Sci 1998;2(10):389-98.

[7] Jarrold C, Baddeley AD. Short-term memory for verbal and visuospatial information in Down's syndrome. Cognitive Neuropsychiatry 1997;2(2):101-22.

[8] Jarrold C, Baddeley AD, Hewes AK. Genetically dissociated components of working memory: evidence from Down's and Williams syndrome. Neuropsychologia 1999;37(6):637-51.

[9] Dykens EM, Rosner BA, Ly TM. Drawings by individuals with Williams syndrome: are people different from shapes? American Journal on Mental Retardation 2001;106(1):94-107.

[10] Lakhan R, Kishore MT. Down syndrome in tribal population in India: a field observation. J Neurosci Rural Pract 2016;7(1):40-3.

[11] Kava MP, Tullu MS, Muranjan MN, et al. Down syndrome: clinical profile from India. Arch Med Res 2004;35(1):31-5.

[12] Kovaleva NV. Sex ratio in Down syndrome. [Article in Russian]. Tsitol Genet 2002;36(6):54-69.

[13] El-Gilany AH, Yahia S, Shoker M, et al. Cytogenetic and comorbidity profile of Down syndrome in Mansoura University Children's Hospital, Egypt. Indian J Hum Genet 2011;17(3):157-63.

[14] Wang YF, Lin L, Chen ZY. Cytogenetic study of Down syndrome cases in southern Hainan Province and report of a rare case of abnormal karyotype. Nan Fang Yi Ke Da Xue Xue Bao 2010;30(11):2592-3, 2595.

[15] Källén B, Mastroiacovo P, Robert E. Major congenital malformations in Down syndrome. Am J Med Genet 1996;65(2):160-6.
[16] Ahmed I, Ghafoor T, Samore NA, et al. Down syndrome: clinical and cytogenetic analysis. J Coll Physicians Surg Pak 2005;15(7):426-9.

[17] Abbeduto L, Warren SF, Conners FA. Language development in Down syndrome: from the prelinguistic period to the acquisition of literacy. Ment Retard Dev Disabil Res Rev 2007;13(3):247-61.

[18] Kent RD, Vorperian HK. Speech impairment in Down syndrome: a review. Journal of Speech, Language and Hearing Research 2013;56(1):178-210.

[19] Pueschel SM, Louis S, McKnight P. Seizure disorders in Down syndrome. Arch Neurol 1991;48(3):318-20.

[20] Capone G, Goyal P, Ares W, et al. Neurobehavioral disorders in children, adolescents and young adults with Down syndrome. Am J Med Genet C Semin Med Genet 2006;142C(3):158-72.

[21] Arya R, Kabra M, Gulati S. Epilepsy in children with Down syndrome. Epileptic Disorders 2011;13(1):1-7.

[22] Lujic L, Bosnjak VM, Delin S, et al. Infantile spasms in children with Down syndrome. Collegium Antropologicum 2011;35(Suppl 1):213-8.

[23] Gupta AN, Kabra M. Diagnosis and management of Down syndrome. Indian J Pediatr 2014;81(6):560-7.

[24] Raut P, Sriram B, Yeoh A, et al. High prevalence of hearing loss in Down syndrome at first year of life. Ann Acad Med Singapore 2011;40(11):493-8.

[25] Nightengale E, Yoon P, Wolter-Warmerdam K, et al. Understanding hearing and hearing loss in children with Down syndrome. Am J Audiol 2017;26(3):301-8.

[26] Wong V, Ho D. Ocular abnormalities in Down syndrome: an analysis of 140 Chinese children. Pediatr Neurol 1997;16(4):311-4.

[27] Rajangam S, Janakiram S, Thomas IM. Dermatoglyphics in Down's syndrome. J Indian Med Assoc 1995;93(1):10-3.

[28] Castilla EE, Lugarinho R, da Graça DM, et al. Associated anomalies in individuals with polydactyly. Am J Med Genet 1998;80(5):459-65.

[29] Brink DS. Transient leukemia (transient myeloproliferative disorder, transient abnormal myelopoiesis) of Down syndrome. Adv Anat Pathol 2006;13(5):256-62.

[30] Choi JK. Hematopoietic disorders in Down syndrome. Int J Clin Exp Pathol 2008;1(5):387-95.

[31] Ali FE, Al-Bustan MA, Al-Busairi WA, et al. Cervical spine abnormalities associated with Down syndrome. Int Orthop 2006;30(4):284-9.

[32] Ram G, Chinen J. Infections and immunodeficiency in Down syndrome. Clin Exp Immunol 2011;164(1):9-16.

[33] Ondarza A, Jara L, Munoz P, et al. Sequence of eruption of deciduous dentition in a Chilean sample with Down's syndrome. Arch Oral Biol 1997;42(5):401-6.

[34] Jyothy A, Rao GN, Kumar KS, et al. Ttanslocation Down syndrome. Indian J Med Sci 2002;56(3):122-6. 